TEME, г. XLIV, бр. 3, јул - септембар 2020, стр. 883-900

Прегледни рад

https://doi.org/10.22190/TEME180919060B

Примљено: 19. 9. 2018.

Ревидирана верзија: 17. 5. 2019.

Одобрено за штампу: 1. 10. 2020.

\title{
MONETARY CHALLENGES OF EMERGING EUROPEAN ECONOMIES TOWARDS THE EURO ZONE
}

\author{
Emilija Beker Pucar \\ University of Novi Sad, Faculty of Economy in Subotica, Subotica, Serbia \\ emilijabp@gmail.com
}

\begin{abstract}
The paper aims to highlight the main difficulties on the monetary path towards the euro zone experienced by Emerging Europe. Emerging European Economies (EEEs), EU members, adopted either double shift or smooth transition monetary approach towards the euro zone. Double shift assumes changes from floating exchange rate regimes (ERRs) to the ERM II target zone and, finally, monetary union as a rigid ERR. The smooth transition is practiced by economies with mainly rigid ERRs before the ERM II entrance and, at the end, again rigid ERR of a monetary union. Despite chosen monetary path towards the euro zone, crucial difficulties or aggravating factors could be identified in the form of real exchange rate appreciation due to productivity growth or capital inflows. A reconciliation of inflation and exchange rate target zone is extremely complex, at the same time striving not to jeopardize the real convergence. What is stressed here is the vicious cycle between real and nominal convergence as the reason why the ERM II target should be regarded as a "waiting room" not as a "training room" in the pre-EMU phase.
\end{abstract}

Key words: euro zone, emerging European economies, nominal convergence, real convergence, ERM II.

\section{МОНЕТАРНИ ИЗАЗОВИ ЕВРОПСКИХ ЗЕМАЉА У РАЗВОЈУ НА ПУТУ КА ЕВРО-ЗОНИ}

\footnotetext{
Апстракт

У раду се идентификују кључне препреке на монетарном путу европских земаља у развоју ка евро-зони. Европске земље у развоју, односно чланице ЕУ, прихватиле су или монетарни приступ двоструке промене или приступ постепене транзиције ка евро-зони. Двострука промена подразумева кретање од флуктуирајућих режима девизног курса ка ERM II таргет-зони и, коначно, монетарној унији, као ригидном режиму девизног курса. Монетарни приступ постепене транзиције су практиковале економије са углавном ригидном формом режима курса пре приступања ERM II, уз, на крају, поновно прихватање ригидног аранжмана монетарне уније. Без обзира на одабрану монетарну путању ка евро-зони, кључне потешкоће или отежавајући фактори могу се идентификовати у форми апресијације реалног девизног курса услед раста продуктивности или прилива капитала. Помирење инфлационог и таргета девизног курса је изузетно сложено, у исто време тежећи да се не угрози процес
} 
реалне конвергенције. У раду истакнути зачарани круг између реалне и номиналне конвергенције представља разлог зашто би ERM II зону требало посматрати као „собу за чекање”, а не „собу за тренирање” у пре-ЕМУ фази.

Кључне речи: евро-зона, европске земље у развоју, номинална конвергенција, реална конвергенција, ERM II.

\section{INTRODUCTION}

By 2018, out of thirteen new EU member states (eleven from the East) seven countries introduced the euro (five from the East). The timing of euro zone joining is uncertain for the other six new member states. There is a schedule, however, the late comers (Croatia, Bulgaria, Romania) are still far away from fulfilling the accession requirements. While Baltic States, Slovakia and Slovenia have adopted the euro, the three Central European economies (the Czech Republic, Hungary, and Poland) take different positions from the others (Palankai, 2015). Their commitment to the early euro zone joining has changed in the last decade and turned to hesitation and even to rejection. These countries have problems fulfilling some of the Maastricht criteria, and none of them are in the Exchange Rate Mechanism (ERM) II target zone.

ERM II is based on the June 161997 Amsterdam Resolution of the European Council on the establishment of an Exchange-Rate Mechanism (ERM) in the third stage of Economic and Monetary Union (European Council, 1997). The Exchange Rate Mechanism II is a modified version of the ERM I, the European Monetary System (EMS) component established in March 1979. ERM II, as one of the convergence criteria on the way to the euro zone, was introduced on January 01, 1999 and represents the direct successor to the original ERM I. A key lesson from the ERM I crisis is the danger of implementing a soft parity, i.e. narrow target zone of $+/-2-25 \%$ around central parity, in the context of high capital mobility (Buiter, Corsetti, \& Pesenti, 1998). The mentioned danger is emphasized in the theory of "impossible trinity" which indicates that it is impossible to apply "soft" parity or intermediate ERR in conditions of free capital movements and full capital integration (Aizenman, Chinn, \& Ito, 2013). The strong capital inflows within the ERM I were encouraged by the existence of the parity that minimized exchange rate (ER) risk along with the expectations of further convergence to the monetary union. As a result of the ERM I vulnerability in the context of liberalized capital flows, two key changes followed. Firstly, the expansion of the ER corridor or widening fluctuation margins from $2.25 \%$ to $15 \%$ in August 1993, while Sweden and the United Kingdom (which left the ERM) switched to floating ERR. The second change is the strengthening of the parity by credibly binding the national economic authorities to a fast and timespecific convergence towards the EMU (Begg, Eichengreen, Halpern, von Hagen, \& Wyplosz, 2003). 
Unlike the ERM I, the ERM II is a bilateral system in which the currencies of the participating countries in the mechanism are related only to the euro, but not to other participating currencies in ERM II. Although participation in the ERM II de jure is not mandatory, it is de facto because all EU countries are striving to join the EMU, while the ERM II is one of the mandatory convergence criteria (De Souza, 2002). In essence, participation in the ERM II for a period of at least two years is the obligation of the new EU member states. While the other convergence criteria are precisely defined, the ERM II criterion is not sufficiently precise. The time frame for the ERM II accession is not fixed and depends on the agreement between the authorities of the new EU member state and the EMU. In principle, the ERM II accession can be a very fast process (several days in the case of Austria), but it is more realistic that the process lasts for about 6 months for technical and logistical reasons.

Basically, three key stages could be identified in the process of monetary convergence towards the euro zone. The first stage of monetary convergence includes the period prior to the entrance into the EU (pre-EU accession period), the second stage between the EU to the euro zone membership (post-EU pre-EMU accession period), while the third stage assumes the functioning within the euro zone (post-EMU accession period) (European Council, 1997; de Grauwe and Schnabl, 2004). It is the aggravating factors in the pre-EMU stage of monetary convergence which delay participation of some EU members in the ERM II target zone that are analyzed in the paper. Thus, the broad aim of the paper is to identify key obstacles on the monetary convergence path and derive conclusions concerning the overcoming of the revealed monetary challenges. In order to shed some light on these issues the paper is structured as follows: Section 2 deals with two monetary approaches in the second phase of monetary convergence - double shift vs smooth transition towards the euro zone; aggravating factors during monetary convergence are stressed within Section 3; while the vicious cycle between real and nominal convergence is described within Section 4. Key concluding remarks are given in the last section.

\section{EXCHANGE RATE AND MONETARY REGIMES: DOUBLE SHIFT VS SMOOTH TRANSITION}

It is complicated to simultaneously target an ER and inflation under the ERM II target zone at the second stage of the monetary convergence. Numerous papers explored the unsustainability aspect of the ERM II in attaining the convergence criteria (Adahl, 2000; Begg, Eichengreen, Halpern, von Hagen, \& Wyplosz, 2003; Fahrholz, 2003; Eijffinger, 2003; Issing, 2003; Polanski, 2004; Tchorek, 2017; etc.). The exclusive focus to inflation target (IT) bears the danger of constant restrictiveness with 
negative consequences to economic activity and employment, i.e. weaker real convergence (Edsel, 2007).

The Exchange Rate Mechanism II represents the target zone with two essential elements or constraints - fixed, central parity against the euro and limited fluctuation band at $+/-15 \%$. It is a relatively flexible framework allowing other alternative ERRs consistent with the requirements of the observed mechanism. The following ERRs are allowed within the ERM II: conventional fixed parity against the euro as a classic fixed-parity form without fluctuation margins; narrow or wider target zone with fluctuation margins up to $+/-15 \%$ with a fixed central parity; currency board - considered as compatible, but concluded on case-by-case basis. However, the following ERRs are unacceptable in the ERM II participation: fixed parity against other currencies (not the euro); free ER floating; crawling pegs; unilateral euroization. Therefore, the elements that must be fulfilled for the participation in the ERM II are: (1) central, fixed (not adjustable, crawling) parity; (2) parity defined to the euro; (3) fluctuation margins that may or may not exist, and if they exist, they must be within $+/-15 \%$ (Backe, Thimann, Arratibel, Calvo-Gonzales, Mehl, \& Nerlich, 2004).

The need for adjusting the ERR within the ERM II framework is a factor that must be taken into account in assessing the impact of the ERM II on national economies. If the ERR in the first phase of EU accession is further away from the target zone or its compatible regime, monetary authorities will face major changes impacting the real economy. It is possible to identify two monetary paths at the second phase of monetary convergence from the aspect of applied ERRs and monetary regimes.

One monetary path is followed by countries that do not change monetary policy regime (ER targeting), nor the ERR (Belhocine, Crivelli, Geng, Scutaru, Wiegand, \& Zhan, 2016). This path represents smooth transition towards the euro zone. Monetary regime of ER targeting in the combination with the currency board or conventional fixed parity against the euro are applied by Estonia, Lithuania, Latvia, and Bulgaria. Bulgaria remained at this group of countries at the second stage of monetary convergence, while Baltic countries are already at the third stage of the euro zone membership (Estonia since 2011, Latvia 2014, Lithuania since 2015). Currency regimes of countries at this monetary path already mimic many features of euro adoption (IMF, 2015). Although Slovenia and Croatia did not follow currency board (rigid ERR) track, they also practiced the observed monetary approach having in mind euro-peg in the first and the second stage of the monetary convergence. The nominal exchange rate of economies belonging to smooth monetary transition towards the euro zone did not change substantially during all the phases of the monetary convergence (Figure 1). Alongside the NER, Figure 1 reveals the years spent in identified stages of the monetary convergence. Slovenia spent three years (2004-2007) in the second (pre-EMU) stage, Slovakia five years (2004-2009), Estonia six 
years (2004-2011), Latvia ten years (2004-2014), and Lithuania eleven years (2004-2015).
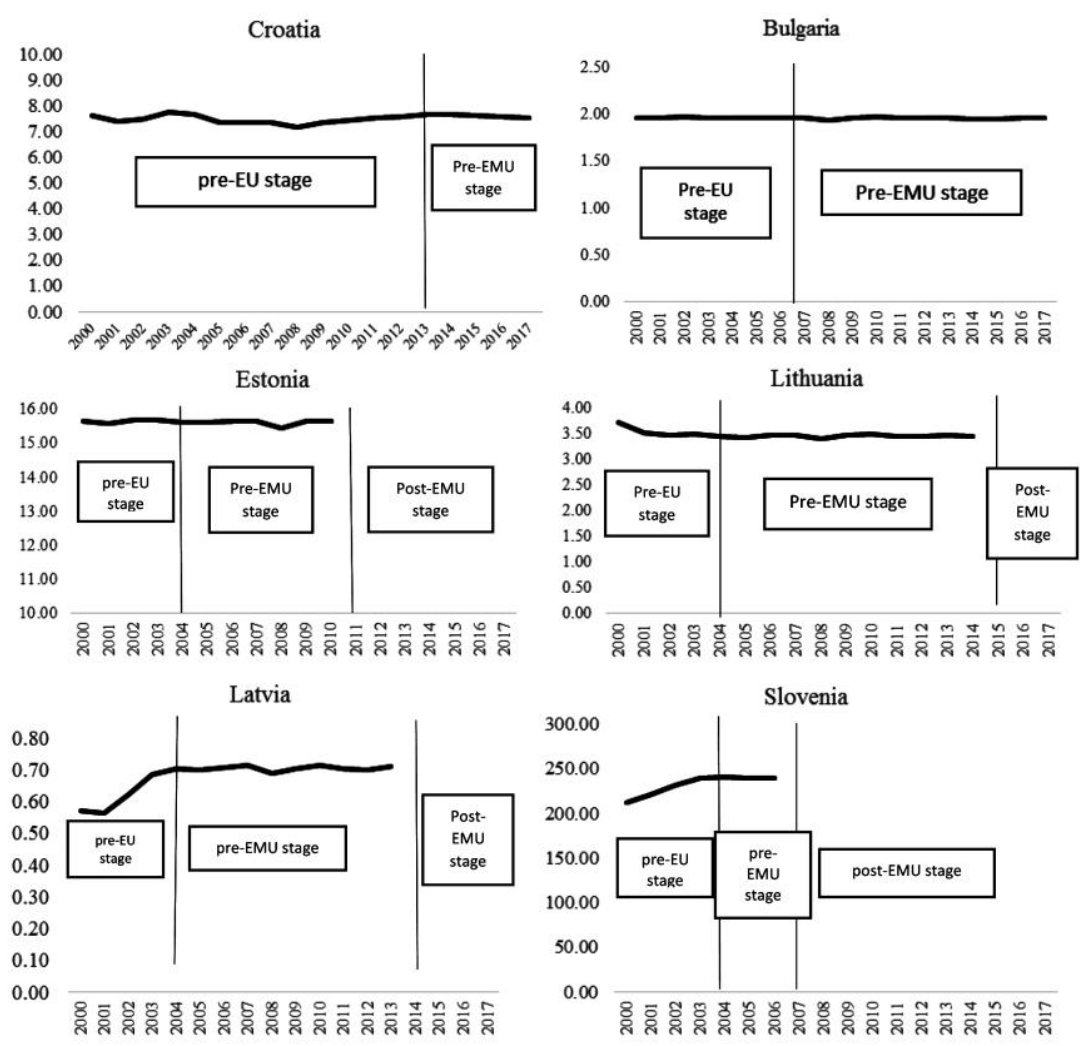

Note: In the case of Slovenia, Estonia, Lithuania and Latvia, nominal exchange rates are presented until euro adoption i.e. in the pre-EU and pre-EMU stage.

Figure 1. Nominal exchange rate (domestic currency per euro) in the period 2000-2017 for EEE's with smooth monetary transition towards the euro zone Source: Authors according to the IMF International Financial Statistics database.

The opposite monetary path at the second stage of monetary convergence does not assume the radical change of monetary policy regime (inflation targeting - IT), although ERR should be adjusted by meeting the Maastricht criteria regarding the ERM II. It is actually a double ER regime shift. Exchange rate flexibility must be reduced by switching from managed/free float to the target zone and, ultimately, by defining the central parity against the euro. Poland, the Czech Republic and Hungary, since 2004, and Romania since 2007 have been at the second phase of the monetary convergence following this monetary path (IMF, 2015; Bakker, 2017). These countries, however, still haven't participated in the ERM II. 
Slovakia followed the same monetary path at the pre-EMU stage (20042009), but it has been, and currently is, at the third stage of the monetary convergence since 2009. See Figure 2 for the identification of NER changes and stages of the monetary convergence of countries belonging to the double shift ERR club. In contrast to ERR that will be de facto exposed to changes in accordance with the progress of the monetary convergence, the monetary regime in the second phase of EMU joining could stay in the form of inflation targeting (IT). However, it is preferable to change the type of the regime. The Exchange Rate Mechanism II participation assumes maintenance of the target zone in the two-year period implying targeting of both variables - ER and inflation - thus making strict IT framework inadequate (Bofinger \& Wollmerhäuser, 2001; Orlowski, 2001, 2005). Changing the type of IT during the monetary convergence points to the dynamic approach to IT framework switching from strict to flexible IT. Nevertheless, the flexible IT might be further extended to the framework that prioritizes low and stable inflation over the ER stability. The monetary policy strategy based on targeting the relative inflation-forecast is believed to be consistent with the Maastricht convergence criteria and can be implemented in concurrence with the ER stability benchmark for the ERM II (Orlowski, 2008).

Regardless of the implemented monetary approach, smooth transition or double shift, experience shows that it is of crucial importance to manage ERR changes in order to ensure further economic development and avoid welfare losses. This is particularly related to choosing the right timing for moving to a new regime which requires special caution. Provided that the ERM II entry is well-timed and that the parity is adequately chosen in line with the underlying fundamentals, the mechanism, with its $\pm 15 \%$ corridor, leaves enough space for adjustments to shocks and economic development. The possibility of changing the central parity under a multilateral agreement would add further room for maneuvers. That especially holds if the real catching-up process is significantly faster than expected and leads to strengthening currency pressure. Therefore, a full use of the wide bands in the ERM II and the communication of the possibility of realignments would, in principle, allow for a considerable ER flexibility. An overly tight ER management "close to the central rates", practiced by Baltic states for example, removes ER as an adjustment tool.

However, if the ERM II entry is not well-timed and the parity is not adequate, the situation concerning real and nominal convergence becomes very complicated. The candidates for the EMU accession need to achieve price stability prior to tying their currencies to the euro. Otherwise, the euro-peg accompanied by inflation persistently higher than that of the euro zone would trigger RER appreciation and worsen their current account position. The next section analyzes the aggravating factors of the participation in the ERM II in more details. 

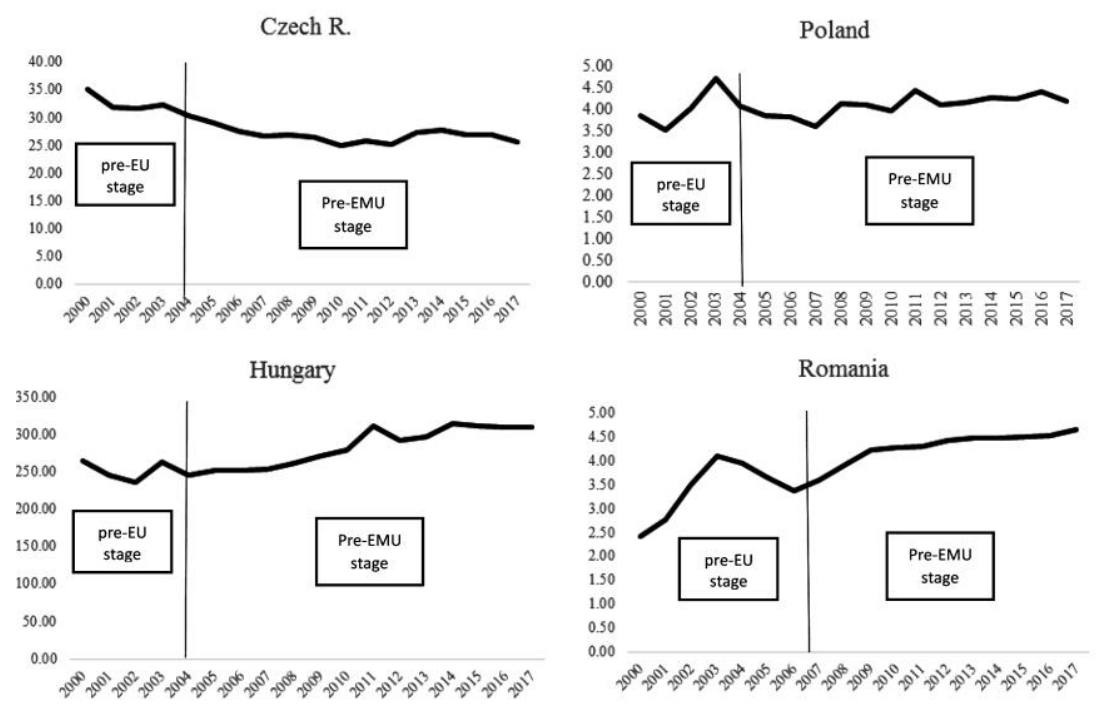

Slovakia

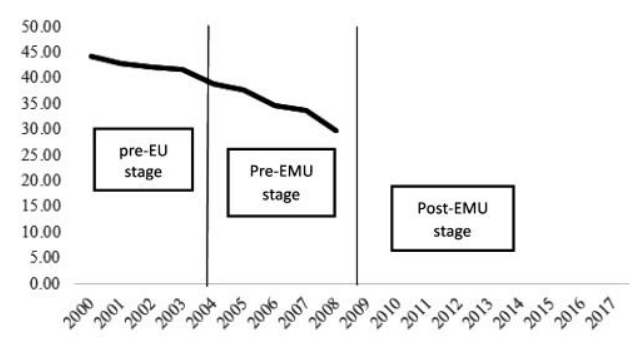

Note: In the case of Slovakia, nominal exchange rate is presented until euro adoption i.e. in the pre-EU and pre-EMU stage.

Figure 2. Nominal exchange rate (domestic currency per euro) in the period 2000-2017 for EEE's with double shift monetary transition towards the euro zone

Source: Authors according to the IMF International Financial Statistics database.

\section{AGGRAVATING FACTORS OF MONETARY CONVERGENCE IN THE PRE-EMU STAGE}

Real convergence is a process in which economic growth in poorer countries is faster than that in richer ones, and in which the real income differences between countries diminish over time. GDP per capita in emerging Europe, as an indicator of real convergence, clearly converges to the euro zone level (Figure 3). 

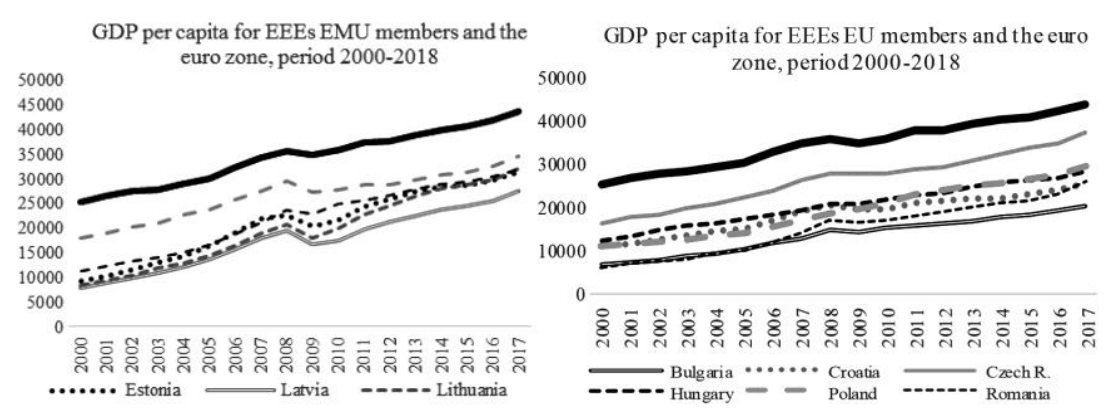

Figure 3. Real convergence towards the euro zone, GDP per capita, PPP, current international \$, 2000-2017

Source: authors according to the WB database, World Development Indicators.

Nominal convergence, expressed as the decrease of inflation rate, is evident for all EEEs. EEEs members of the euro zone (Figure 4, left) in the observed period converged towards the euro-zone inflation rate. The inflation gap has shrunk during monetary convergence and completely narrowed after euro acceptance of the observed countries. The surge of the inflation rate is evident during the Global crisis for Baltic States in preEMU accession phase. These countries were mostly hit with the crisis among EEEs and, even further, among EEs as a whole (Josifidis, Allegret, \& Beker Pucar, 2011, 2014; Allegret \& Sallenave, 2015). Concerning EU members outside the euro zone (Figure 4, right) Romania experienced the highest inflation rate around $46 \%$ in 2000 , however, monetary convergence followed as in other EEEs. The inflation rise was evident during the crisis period, especially in Bulgaria, Romania and Hungary, but in post-crisis period convergence continued.
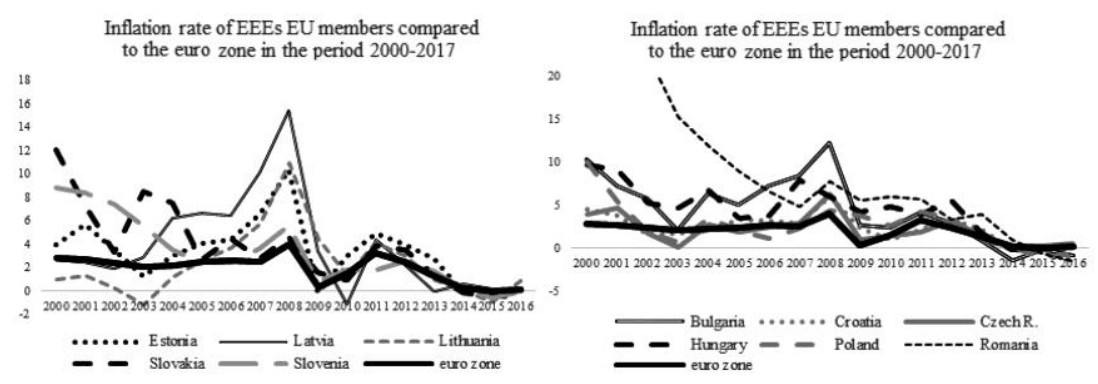

Figure 4. Nominal convergence towards the euro zone, inflation rate, 2000-2017

Source: authors according to the WB World Development Indicators database.

On the convergence path towards the EU, later the EMU, candidate countries face two fundamental, accompanying factors of the convergence 
process that initiate RER appreciation - productivity growth and capital inflows. Countries that are in the process of catching up normally display strong productivity growth in the tradable sector, while productivity developments in the non-tradable sector are normally more similar across countries. Given that productivity growth in the tradable sector exceeds productivity growth in the non-tradable sector, the prices of non-tradable products also grow thanks to the equalizing wages between these sectors. Hence, higher inflation rate in emerging countries in relation to the euro zone stems from higher productivity growth, while RER appreciation could be regarded as a natural and fundamental part of the "catching-up" process (De Haan, Hoeberichts, Maas, \& Teppa, 2016). The Balassa-Samuelson effect is accordingly regarded as a real source of RER appreciation and attached to the process of convergence in living standards across economies.
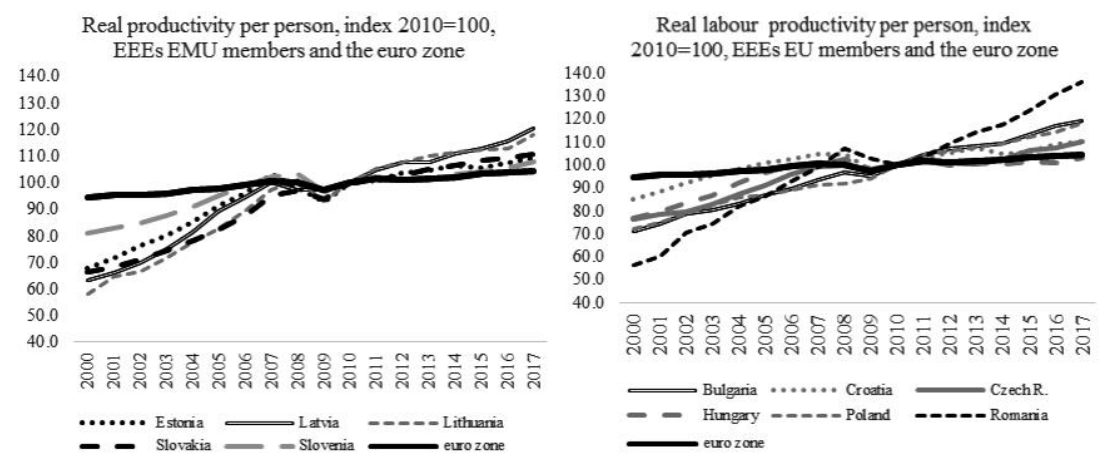

Figure 5. Productivity rise as a catching-up indicator for EEEs EU and EMU members in the period 2000-2017

Source: authors according to Eurostat database.

All EEEs EU and EMU members experienced real labor productivity growth as the accompanying factor of the catching up process towards the euro-zone (Figure 5). Expectedly, productivity catching up is more emphasized for the less developed EEEs, like Romania and Bulgaria. From low starting positions EEEs have shown accelerated productivity gains over the developed euro zone countries. Productivity differential surely reflects on their price level. Despite the obvious nominal convergence, the price level still remains above the euro zone level for most EEEs (see Figure 4).

However, the empirical evidence suggests that the Balassa-Samuelson effect can only provide a partial explanation for the inflation differentials between EU members (Del Hoyo, Diaz, Dorrucci, Heinz, \& Muzikarova, 2017). The vulnerability of EEEs on the monetary path towards the euro zone is also reflected in capital inflows. In addition to the productivity growth as a real source of RER appreciation, capital inflows are also a natural and accompanying phenomenon of the converging process. It arises from the 
initial need for import accumulation due to insufficient domestic savings in order to begin and sustain the catching-up. High investment rates appear essential for convergence towards higher-income EU/EMU countries. Due to large saving gaps in an environment of limited domestic savings in most EEEs, the investments are dominantly financed with capital inflows (Żuk, Polgar, Savelin, del Hoyo, \& König, 2018). The gap between saving and investment is reflected in current account deficit (Figure 6).
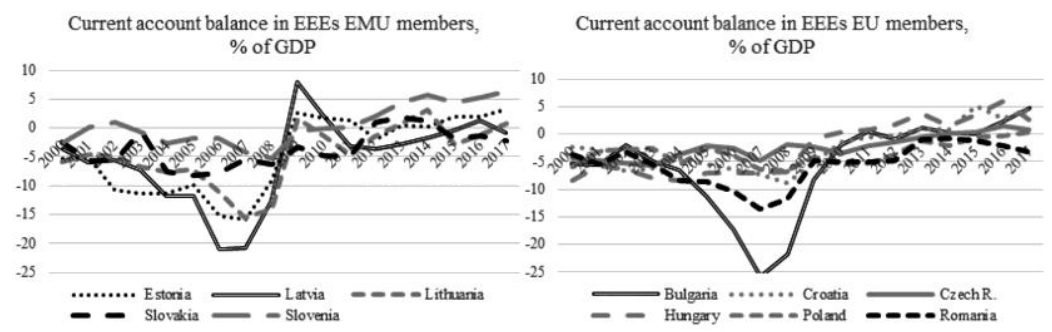

Figure 6. Current account balance in EEEs, \% of GDP, 2000-2017 Source: authors according to the WB World Development Indicators database.

The external deficit position is justified if it is a reflection of the convergence process and fostering of economic growth. In this sense, the import of foreign accumulation is understandable. However, another part of the deficit is unjustified and unsustainable since capital inflows are directed into the consumption initiating excessive economic overheating prior to the crisis. The economic overheating goes along with the accumulation of current account deficit which culminates in the pre-crisis and pre-EMU stage. This is the reason of abrupt external adjustment in the post-crisis period (Figure 6). The position of the Baltic States was especially vulnerable within the EMU member group. These economies experienced the highest current account deficit (relative to GDP) in the pre-EMU stage accompanied with sharp current account adjustment in the post-crisis period. The same holds for Bulgaria and Romania which expressed the most vulnerable external position between EU members.

The urge to foster the economic growth under low domestic saving and the need to cover current account deficit brought the need for capital inflows in EEEs. The downside of large capital inflows entails the risks of volatility and speculative pressures on ER. Moreover, when market participants pay attention to the growing current account deficits, the side effect of large capital inflows (as a signal of vulnerability and possible overvaluation) can create their own demise. The vulnerability of EEEs to the sudden stop episodes has been revealed, and especially in the period of the Global crisis since 2008 (Rahman, 2008; Shelburne, 2008; Vamvakidis, 2008; Allegret \& Sallenave, 2015). Figure 7 shows that (i) in average, foreign direct investments (FDI) and portfolio inflows (PI) in EEEs are far lower from the euro zone level (left panel); (ii) in general, FDI capital 
inflows in EEEs dominate over the variable portfolio investments in the observed period 2000-2017 (right panel); (iii) the capital surge in the precrisis period is evident as a vulnerability grounds for sudden stop problems in EEEs (right panel); (iv) the abrupt FDI drop and milder drop of portfolio investments happened under the crisis impact in EEEs, as well as the euro zone (right panel).
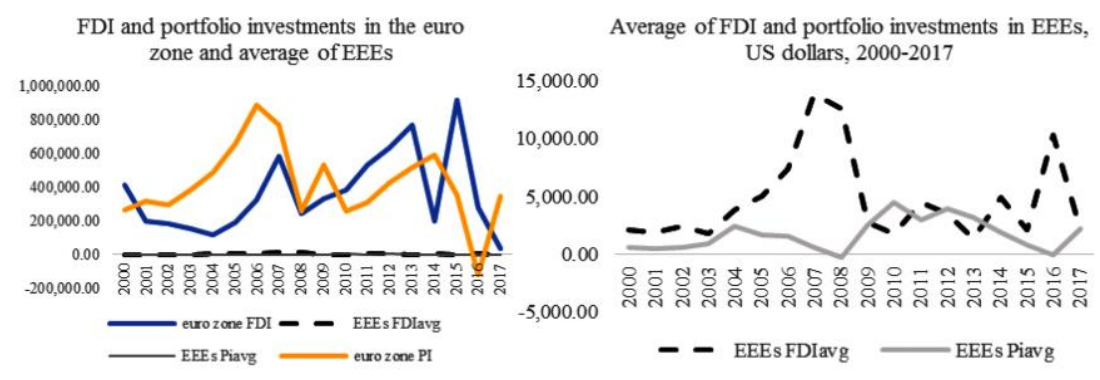

Figure 7. FDI (net incurrence of liabilities) and portfolio investments (net incurrence of liabilities) in the euro zone and EEEs (average), US dollars, 2000-2017

Source: authors according the IMF International Financial Statistics database

Some EEEs have partly managed such vulnerabilities through flexible ER arrangements (double shift monetary stance from the previous section) which weaken the pressure of monetary authorities concerning speculative attacks and foreign exchange interventions (Josifidis, Allegret, \& Beker Pucar, 2011, 2014). However, the unavoidable participation in ERM II in the second stage directly gives the speculators the target (euro-peg) with fluctuation bands, diminishing the role of ER as a shock absorber.

\section{THE VICIOUS CYCLE BETWEEN REAL AND NOMINAL CONVERGENCE IN THE ERM II}

Real convergence as a catching-up growth in income and adjustment of the real economic structures towards those prevailing in the euro area, in combination with the nominal convergence, makes the ERM II difficult to sustain. EU member states, and candidates for EMU accession, try to participate in the ERM II for as short period of time as possible because of the conflict between real and nominal convergence, as well as the Maastricht criteria related to inflation and ER. Numerous papers investigate the nonsustainability of the ERM II as an intermediate ERR from the aspect of simultaneous realization of the ER and inflation target. The references show that simultaneous achievement of the nominal convergence (ER and inflation stability) and the real convergence (faster economic growth) is almost impossible (Adahl, 2000; Buiter \& Grafe, 2002; De Broeck \& Slok, 2002; 
Begg, Eichengreen, Halpern, von Hagen, \& Wyplosz, 2003; Fahrholz, 2003; Eijffinger, 2003; Issing, 2003; De Grauwe \& Schnabl, 2004; Polanski, 2004; Tchorek, 2017; etc.).

Undoubtedly, there is a close link between convergence in real incomes (real convergence) and convergence in prices (nominal convergence). Figure 8 suggests a positive correlation between real convergence (presented with GDP per capita growth) and nominal convergence (presented with inflation i.e. consumer prices growth) in the period 2000-2018 for EEEs EU members. A progress in real convergence reflected in growing GDP per capita is connected with higher prices as a threat to nominal convergence.

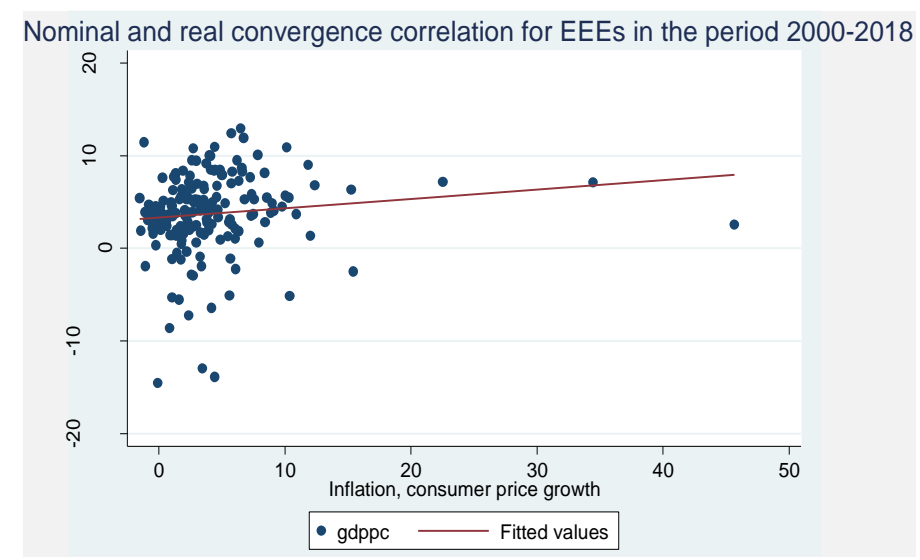

Figure 8. Conflict between nominal and real convergence in the period 2000-2018

Source: authors' calculations, Stata 12, World Bank World Development Indicators database.

The conflict between nominal and real convergence is especially emphasized having in mind the catching-up process accompanied by strong capital inflows and productivity growth. Although fundamental, accompanying factors of the transitional "catching-up" process, these factors also create inflationary pressures as a threat to the inflationary convergence criteria. Productivity growth directly implies a higher price level, while the factor of capital inflows creates redundant liquidity. Capital inflows as a monetary source and higher productivity growth as real source, both initiate RER appreciation. However, how the economy adjusts depends from the applied ERR (De Grauwe \& Schnabl, 2004).

EEEs with gradual monetary stance (i.e. with fixed/rigid ERR) in the pre-EU and pre-EMU stages are usually condemned to fiscal tightening. Higher price level has been dampened via restrictive policies since NER appreciation is not an option. Countries which use ER as a nominal anchor 
must adjust through prices or wages (internal devaluation). On the other hand, EEEs with double shift monetary approach benefit from NER movements (ER as a shock absorber) in all phases of the monetary convergence. Indeed, during the pre-EMU stage, these economies could use NER appreciation (however, limited with lower fluctuation band) to deal with higher productivity without sharp price adjustments. It seems that NER appreciation within the ERM II is a less painful option, but only for countries practicing IT monetary strategy. For others, price level must be controlled via fiscal tightening which threatens real convergence (Badia \& Segura-Ubiergo, 2014). It should be noted that restrictive monetary policy does not solve the problem of capital inflows, endangers interest rate criteria and real convergence process. An unjustified high interest rate on the basis of uncovered interest parity attracts capital with a speculative, short-term nature, the effect of which must be absorbed (Begg, Eichengreen, Halpern, von Hagen, \& Wyplosz, 2003; DGTPE, 2008). Maintenance within the ERM II in the mentioned circumstances of strengthening monetary restrictiveness implies the costs of sterilizing additional liquidity.

Due to the difficulties encountered by emerging economies in the phase of preparation for EMU accession, some authors (Szapary, 2000; Buiter \& Grafe, 2002; De Broeck \& Slok, 2002; Grauwe \& Schnabl, 2004; Tchorek, 2017) suggest changes in the ER and inflation convergence criteria in terms of relaxing one of the criteria. Although the disputed convergence criteria are predicted for countries of a similar level of development (and which did not have to go through the transition process), there is no indication of their redesigning for emerging economies (Bofinger, 2005). Criteria modifications would be regarded as a violation of the principle of equal treatment.

In essence, it is extremely difficult and challenging for monetary authorities not to endanger real convergence if they want to meet ER and inflation convergence criteria. The position of the EU institutions (European Commission and European Central Bank), known as Eurosystem position, indicates the ERM II as a disciplinary mechanism conducive to nominal convergence or the "training room". This view presumes that the ERM II supports the fulfilment of the other convergence criteria by enhancing macroeconomic stability, promoting real convergence, thus bringing member states closer to the euro adoption. According to this stance, the ER fluctuation band and the period in the ERM II should be consistent with the real convergence process and structural characteristics of the economy.

However, the detected vicious cycle between nominal and real convergence contradicts this approach in the pre-EMU stage. In this sense, other views presume the ERM II as a "waiting room" for entry into the euro zone rather than a "training room" (Polanski, 2004). Namely, it is difficult to carry out significant reforms and convergence to the EMU within the ERM II framework. Acceding countries' position regards the ERM II as an 
institutional requirement for the adoption of the euro that cannot be avoided, but one whose appropriateness as an ER policy framework is questionable. Countries should perceive the ERM II as a "waiting room" that offers at best little value-added and may even entail certain risks (Backe, Thimann, Arratibel, Calvo-Gonzales, Mehl, \& Nerlich, 2004). In other words, most of the process of nominal convergence, fiscal and structural reforms must already be completed before entering the ERM II (Schadler, Drummond, Kuijs, Margasova, \& van Elkan, 2005). With such an interpretation, the ERM II is primarily seen as an element of formal obligations on the road to the euro zone rather than a tool to increase macroeconomic stability. Accordingly, the period spent in the ERM II should be limited to the legally required minimum of two years.

The scenario, known as a "training room within waiting room" was to some extent implemented in the Baltic states which have implemented currency board arrangement (gradual monetary approach) within the ERM II. After joining the EU, these economies introduced their currencies to the ERM II, believing that they would meet the criteria and adopt the euro (Tchorek, 2017). Credit booms and the subsequent crisis in the euro zone made it impossible to maintain and foster nominal convergence criteria. Internal devaluation in the Baltic states was severe and accompanied by socially painful adjustments during the Global crisis. It is directly related to rigid ERR which came under pressure under abrupt external shocks (Kang \& Shambaugh, 2014). Given that there is always a risk of remaining in the ERM II longer than the required minimum of two years, a more reasonable solution seems to be the choice of the standard $\pm 15 \%$ fluctuation margins. A wider band or a corridor may be adjusted, offering more flexibility for the macroeconomic policy instruments.

Although the role of fiscal policy is not the focus of this paper, it is clear that fiscal policy must be coordinated with monetary policy. Adequate fiscal policy is the only way to simultaneously achieve nominal and real convergence along with the implementation of structural changes (Fahrholz, 2003). It should not act too expansively in order to avoid endangering the targets within the ERM II. The fiscal position, especially in the form of convergence criteria (budget deficit and public debt), largely determines the time of entry into the ERM II, as well as the length of the EMU accession phase. Although it sounds paradoxical, the entry of former transitional economies into the EMU is primarily conditioned by non-monetary factors (Polanski, 2004). Nominal convergence is increasingly dependent on the structural changes or the process of real convergence. In this context, it makes sense to postpone the entry of EEEs (Poland, the Czech Republic, Hungary, Romania, Bulgaria, Croatia) into the ERM II until an adequate, desirable level of real and nominal convergence is established, in particular until a solid fiscal position and sustainable public finances are ensured (Onorante, 2006). A solid and disciplined fiscal policy could relax the position of monetary policy, and vice versa. 


\section{CONCLUDING REMARKS}

It is not possible to provide great progress in the convergence processes in the ERM II phase. Basic requirements for a successful experience in the euro zone should be in place prior to euro adoption. Real convergence should be aligned closely enough with the euro zone in order to minimize risks of that unique monetary policy which can be inappropriate for the domestic conditions. Following the same line of thought, alternative adjustment mechanisms to the loss of monetary policy sovereignty, especially wage/price flexibility and fiscal policy, must be capable of absorbing shocks since ER cannot act as a shock buffer anymore. Conversion rates must be appropriate, sustainable, realistic, i.e. based on macroeconomic fundamentals. Therefore, adequate balancing between satisfying the numerical (nominal) convergence criteria without braking real convergence could be regarded as a success of participating in ERM II.

Aggravating factors of the participation within ERM II are the conflict between nominal and real convergence emphasized through the catching-up side effects, i.e. capital inflows and productivity growth. Capital inflows and productivity growth pose threats to the inflation or ERM II Maastricht criteria. The expected reactions of the economic authorities are in the form of a restrictive monetary or restrictive fiscal policy with negative effects on the real convergence. However, restrictive monetary policy, although in charge of nominal convergence, attracts speculative portfolio capital with clear destabilizing monetary effects. Sterilization is imposed as a potential measure of absorption of excessive liquidity, but this measure is not a solution, since high-yield short-term capital is attracted again. The second option is a tight fiscal policy that does not assume additional, negative measures (such as sterilization in the case of restrictive monetary policy), but causes direct negative consequences for real convergence. Bearing in mind that within the ERM II restrictive monetary and fiscal policies are almost unavoidable, and that solutions to successful and simultaneous real and nominal convergence are practically nonexistent, the only acceptable proposal for EEEs in the preEMU stage is completing the process of real convergence before joining the ERM II. Due to the vicious cycle in combining nominal and real convergence, it is desirable to fulfill the criteria of nominal convergence or at least introduce it at the final stage.

There is a risk to consider the EU integration as a magic way to accelerate the economic growth and focusing on the immediate entry into the euro zone. Vulnerability to higher inflation due to productivity growth and capital account volatility (or massive capital inflows), the consequent RER appreciations, but also the rapid credit and demand growth, together represent aggravating factors of smooth transition towards the euro zone. Prior the ERM II participation inflation should be low, fiscal adjustment should be well structured and substantial, central parities should be set realistically and monetary frameworks (ER targeting or modified IT) 
during ERM II should incorporate adequate protection mechanism from capital account reversals. Accordingly, two years of participation in ERM II should be regarded as "waiting room", not "training room" for joining the euro zone. Despite this general background, economic merits of any particular strategy towards ERM II and the later adoption of the euro will need a careful case-by-case assessment. In spite of identified monetary challenges and potential solutions for EEEs, further research should be directed to specific countries in the positions of double shift or gradual monetary track towards the euro zone.

\section{REFERENCES}

Allegret, J-P., \& Sallenave, A. (2015). Capital flow bonanzas and monetary policy in emerging Europe: responses to the global financial crisis. Post-Communist Economies, 27, 429-447. doi: https://doi.org/10.1080/14631377.2015.1084709

Aizenman, J., Chinn M.D., \& Hiro, I. (2013). The 'impossible trinity' hypothesis in an era of global imbalances: measurement and testing. Review of International Economics, 21(3), 447-458. doi: http://dx.doi.org/10.2139/ssrn.2071311

Adahl, M. (2000). Accession countries' choice of exchange rate system in preparation for EMU. http://www.riksbank.se/upload/Dokument_riksbank/Kat_publicerat/Artiklar _PV/er00_4_artikel3.pdf.

Backé, P., Thimann, C., Arratibel, O., Calvo-Gonzalez, O., Mehl, A., \& Nerlich, C. (2004). The acceding countries' strategies towards ERM II and the adoption of the euro: An analytical review. ECB Occasional Paper Series 10.

Badura, M., \& Segura-Ubiergo, A. (2014). Real exchange rate appreciation in emerging markets: Can fiscal policy help? IMF Working Paper 14/1.

Bakker, B. B. (2017). Exchange rate regimes in emerging Europe. $5^{\text {th }}$ Regional Meeting of Governers, Umag, March 30-31.

Begg, D., Eichengreen, B., Halpern, L., von Hagen, J., \& Wyplosz, C. (2003). Sustainable regimes of capital movements in accession countries. CEPR Policy Paper 10.

Belhocine, N., Crivelli, E., Geng, N., Scutaru, T., Wiegand, J., \& Zhan, Z. (2016). Taking stock of monetary and exchange rate regimes in emerging Europe. IMF European department paper.

Bofinger, P., \& Wollmershäuser, T. (2001). Is there a third way to EMU for the EU accession countries? Economic Systems, 25(3), 253-274.

Bofinger, P. (2005). Exchange rate policies and institutional arrangements in the transition process to European Monetary Union. EUI Working Paper RSCAS 2004/17.

Buiter, W., Corsetti, G., \& Pesenti, P. (1998). Interpreting the ERM crisis: country specific and systemic issues. Princeton studies in international finance 84 .

Buiter, W., \& Grafe, C. (2002). Anchor, float or abandon ship: Exhange rate regimes for the Accession countries. EIB papers 7(2).

De Souza, L. M. V. (2002). Beyond transition: Essays on the monetary integration of the accession countries in Eastern Europe ( $\mathrm{PhD}$ thesis). Retrieved from http://www.tinbergen.nl/ phare/Partners/phdfinal.pdf.

De Broeck, M., \& Sløk, T. (2001). Interpreting real exchange rate movements in transition countries. IMF working paper 01/56; BOFIT discussion paper 7/2001.

De Haan, J., Hoeberichts, M., Maas, R., \& Teppa, F. (2016). Inflation in the euro area and why it matters. De Nederlandsche bank Eurosystem occasional studies 14-3.

Del Hoyo, J. L. D, Dorrucci, E., Heinz, F. F., \& Muzikarova, S. (2017). Real convergence in the euro area: a long-term perspective. ECB occasional paper 203. 
Direction Generale Du Tresor Et De La Politique Economique - DGTPE. (2008). Real exchange rate appreciation in the emerging countries. Tresor-Economics, 35, 4.

Żuk, P., Polgar, E. K., Savelin, L., del Hoyo, J. L. D., \& König, P. (2018). Real convergence in Central, Eastern and South-Eastern Europe. ECB economic bulletin, issue $3 / 2018$.

Edsel, B. (2007). Win or lose, it's the policy we choose: comparative economic performance of the inflation targeters. MPRA Paper 2928.

Eijffinger, S. C. W. (2003). Accession countries and ERM II. Briefing Paper on "The conduct of monetary policy and an evaluation of the economic situation in Europe - 3rd quarter 2003 (august 2003)" for the European Parliament. http://www.europarl.europa.eu/comparl/econ/pdf/emu/speeches/20030910/eijf finger.pdf

European Council. (1997). Resolution of the European Council on the establishment of an Exchange-Rate Mechanism in the Third Stage of Economic and Monetary Union. Amsterdam, 16 June 1997(97/C 236/03). https://www.nationalbanken.dk/en/...rate .../The\%20Amsterdam\%20Resolution.pdf

Fahrholz, C. (2003). Strategic exchange-rate policy of accession countries in ERM II. Ezoneplus working paper 14. http://www.ezoneplus.org/archiv/ezoneplus_wp_ fourteen.pdf

International Monetary Fund - IMF. (2015). Central and Eastern Europe: New member states (NMS) policy forum - selected issues. IMF country report 15/98.

Issing, O. (2003). Considerations on monetary policy strategies for accession countries. http://www.ecb.int/press/key/date/2003/html/sp030228.en.html.

De Grauwe, P., \& Schnabl, G. (2004). Exchange rate regimes and macroeconomic stability in Central and Eastern Europe. CESifo working paper 1182.

Josifidis, K., Allegret, J-P., \& Beker Pucar, E. (2011). Inflation targeting and exchange rate regimes in Serbia and selected transition economies. Eastern European Economics, 49(4), 88-105. doi: https://doi.org/10.2753/EEE0012-8775490405

Josifidis, K., Allegret, J-P, \& Beker Pucar, E. (2014). Adjustment mechanisms and exchange rate regimes in 2004 new EU members during the financial crisis. PostCommunist Economies, 25(1), 1-17. doi: https://doi.org/10.1080/14631377.2013. 756614

Kang, J. S., \& Shambaugh, J. C. (2014). Progress towards external adjustment in the euro area periphery and the Baltics. IMF working paper 131.

Onorante, L. (2006). Fiscal convergence before entering the EMU. ECB working paper 664.

Orlowski, L. T. (2001). From inflation targeting to the euro-peg, A model of monetary convergence for transition economies. Economic Systems, 25, 233-251. doi: https://doi.org/10.1016/S0939-3625(01)00020-6

Orlowski, L. T. (2005). Monetary policy adjustments on the final passage towards the euro. Center for social and economic research, Warsaw. http://www.case-research.eu/ upload/publikacja_plik/4830919_sa294ok.pdf

Palankai, T. (2015). The introduction of the euro and Central Europe. Economics and Sociology, 8(2), 51-69. doi: 10.14254/2071-789X.2015/8-2/5

Polanski, Z. (2004). Poland and the euro zone enlargement: Monetary policy, ERM II, and other issues. http://www.defi-univ.org/IMG/pdf/23.pdf.

Rahman, J. (2008). Current account developments in new member states of the European Union. IMF working paper 92.

Schadler, S., Drummond, P., Kuijs, L., Margasova, Z., \& van Elkan, R. (2005). “Adopting the euro in Central Europe - challenges of the next step in European integration. IMF occasional paper 234. 
Szapary, G. (2001). Transition countries' choice of exchange rate regime in the run-up to EMU membership. Finance \& Development, 38(2).

Shelburne, R. C. (2008). Current account deficits in European emerging markets. UNECE discussion paper 2008.2.

Tchorek, G. (2017). Polish exchange rate policy dilemmas in ERM II. Studia Europejskie, 2/2017, 43-67.

Vamvakidis, A. (2008). Convergence in emerging Europe: Sustainability and vulnerabilities. IMF working paper 181.

\title{
МОНЕТАРНИ ИЗАЗОВИ ЕВРОПСКИХ ЗЕМАЉА У РАЗВОЈУ НА ПУТУ КА ЕВРО-ЗОНИ
}

\author{
Емилија Бекер Пуцар \\ Универзитет у Новом Саду, Економски факултет у Суботици, Суботица, Србија
}

\section{Резиме}

Након приступања Европској унији, европске земље у развоју суочавају се са значајним изазовом при дизајнирању стратегије девизног курса и монетарне политике у процесу транзиције ка евро-зони. Европске земље у развоју морају одлучити какву ће монетарну путању пратити у периоду пре укључења у ERM II и, имајући у виду шири $\pm 15 \%$ коридор, у одређеној мери током учешћа у ERM II. Недостатак ERM II представља институционална структура прилагођена ситуацији ужег коридора и релативно сличним (развијенијим) економијама. Таргет-зона ERM II ограничава маневарски простор економским властима европских земаља у развоју. Према томе, није изненађујуће то што неке од земаља настоје што краће учествовати у некомфорној „соби за чекање”. Европске земље у развоју прихватиле су или режим двоструке промене или градуелни монетарни приступ ка евро-зони. Земље које су практиковале приступ двоструке промене започеле су монетарну конвергенцију са флуктуирајућим режимом девизног курса до ERM II таргет-зоне, приступајући на крају монетарној унији као ригидном аранжману девизног курса. Градуелни приступ монетарној транзицији ка евро-зони практикован је од стране земаља са ригидним девизним и монетарним режимом пре ERM II и након њега у форми валутног одбора и монетарне уније, наведеним редоследом. Међутим, независно од одабране монетарне путање ка евро-зони, отежавајући фактори настају у форми апресијације реалног девизног курса, иницирани растом продуктивности или приливима капитала. Помирење инфлационог таргета и таргета девизног курса унутар ERM II, уз одржавање или убрзавање процеса реалне конвергенције, представља изузетно сложен задатак за економске власти европских земаља у развоју. Рестриктивна фискална и монетарна политика имају негативан ефекат по реалну конвергенцију ка евро-зони. Имајући у виду наглашене отежавајуће факторе у процесу монетарне конвергенције, пре укључења у ERM II пожељно је финализирати реалну конвергенцију, уз ниску инфлацију, добро структурирано фискално прилагођавање и реалистично постављен централни евро-паритет. Зачарани круг између реалне и номиналне конвергенције један је од кључних разлога зашто би ERM II критеријум из Мастрихта требало сматрати „собом за чекање”, а не „собом за тренирање” у фази пре прикључења евро-зони. 